\title{
Myrtaceae, Myrcia squamata (Mattos and D. Legrand) Mattos and Myrceugenia seriatoramosa (Kiaersk.) D. Legrand and Kausel in Santa Catarina: Distribution extension
}

\author{
Fábio Christiano Speck Vieira ${ }^{1^{*}}$ and Karin Esemann de Quadros ${ }^{2,3}$ \\ 1 Universidade de São Paulo, Programa de Pós-graduação em Ciências Biológicas - Botânica, Laboratório de Sistemática vegetal. Rua do Matão, \\ Butantã. CEP 0558-090. São Paulo, SP, Brazil. \\ 2 Universidade da Região de Joinville, Departamento de Ciências Biológicas, Herbário Joinvillea (JOI). Rua Tenente Antonio João, Campus \\ Universitário s/n, Bom Retiro. CEP 89219-905. Joinville, SC, Brazil. \\ 3 Universidade Regional de Blumenau, Departamento de Ciências Naturais. Rua Antônio da Veiga, 140, Victor Konder, CEP: 89012-900, \\ Blumenau, SC, Brazil. \\ * Corresponding author. E-mail: fcsvieira@usp.br
}

\begin{abstract}
Myrtaceae have pantropical distribution, with about 3,500 to 5,800 species in the world, and about 1,000 in Brazil. In Santa Catarina state, 23 species of Myrceugenia and 37 species of Myrcia, included Gomidesia in this genus, are known. Collection trips were made in the cities of Garuva and Joinville, where Myrcia squamata and Myrceugenia seriatoramosa were found for the first time in Santa Catarina. Currently, 38 species of Myrcia and 24 of Myrceugenia are confirmed, increasing the number of Myrtaceae species in this state.
\end{abstract}

Myrtaceae have pantropical distribution, with about 144 genera (Judd et al. 1999) 3,500 to 5,800 species in the world (Lima and Guedes-Bruni 2004), and about 1,000 in Brazil (Schultz 1984). The Brazilian species of Myrtaceae, are characterized for wood habit, leaves opposite, simple, entire, with pellucid glands containing ethereal oils. (Judd et al. 1999, APG III 2009). For the state of Santa Catarina, 23 species of Myrceugenia (Legrand and Klein 1970; Landrum 1981; 1984; Sobral 2003) and 37 species of Myrcia (included Gomidesia in this genus, Sobral 2003; Legrand and Klein 1967, 1969, 1977), are cited.

Collection trips were made from May/2004 to June/2006 in high montane and montane ombrophilous dense forest (Veloso 1992) on Monte Crista, Garuva municipality, and on Castelo dos Bugres, in Joinville municipality, in Santa Catarina state, where two species were collected for the first time in the state.

The maps (Figures 1 and 2) were built with DIVA-GIS 5.2. The geographic coordinates in Santa Catarina state, taken in field and the additional ones were taken from MBM herbarium and literature (Lima and Guedes-Bruni 2004; Landrum 1981) and data bank hosted in CRIA (2008).

Myrcia squamata Mattos and D. Legrand and Myrceugenia seriatoramosa (Kiaersk.) D. Legrand and Kausel, are first recorded for the state of Santa Catarina. Now 38 species of Myrcia and 24 of Myrceugenia are assigned, increasing the number of Myrtaceae species in the state. This two species are found in Garuva and Joinville municipality. Samples of plants are hosted in Joinvillea Herbaria (JOI) of the UNIVILLE (Universidade da Região de Joinville).

Myrceugenia seriatoramosa (Kiaersk.) D. Legrand and Kausel, Comun. Bot. Mus. Hist. Nat. Montevideo 2(28):
5. 1953.

= Eugenia seriato-ramosa Kiaersk., Enum. Myrt. Bras. 170. 1893.

= Luma seriato-ramosa (Kiaersk.) Burret, Notizbl. Bot. Gart. Berlin-Dahlem 15: 528. 1941

Small tree $5-6 \mathrm{~m}$ high. Twigs flattened when young. Trichomes present in the stems, bracteoles and ovary. Leaves elliptic, apex acuminate, base attenuated 4,2-5/1,8$2 \mathrm{~cm}$, glabrous. Peduncles uniflorous, flattened, solitary, or 2-3(4) in row in the leaf axils. Bracteoles ovate. Calyx-lobes orbicular, with pellucid glands. Ovary 2-3-locular (Figure 3).

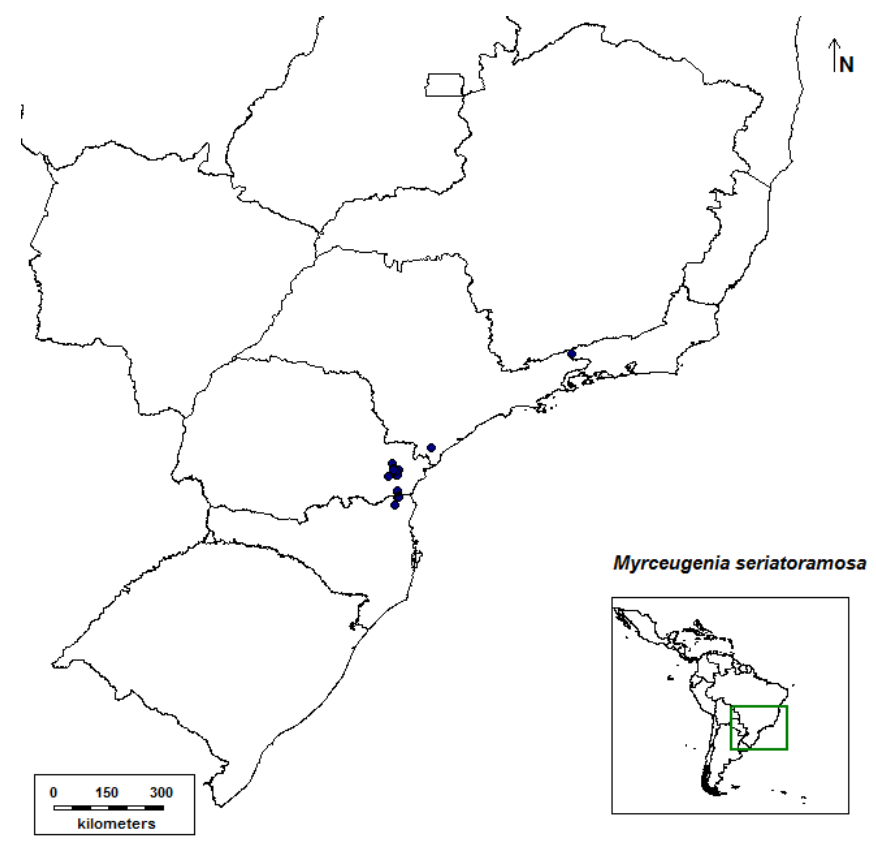

FigurE 1. Distribution of Myrceugenia seriatoramosa (Kiaersk.) D. Legrand and Kausel. 
Geographic Distribution: Santa Catarina state: Joinville and Garuva; Paraná state: Piraquara, Rio de Janeiro state: National Park of Itatiaia; Brazil: from the National Park of Itatiaia to the Northeastern of Santa Catarina state.

Material examined: BRAZIL. Santa Catarina: Joinville, Castelo dos Bugres, 6-VI-2004, F.C.S. Vieira 345 (JOI). Ibidem, 26-III-2005, F.C.S. Vieira 935 (JOI, MBM, BHCB, RB). Garuva, Morro do Campo Alegre, 7-IX-2005, F.C.S. Vieira 1286 (JOI). Paraná: Piraquara, Morro Anhangava, 8-IV-1951, G.G. Hatschbach 2226 (MBM).

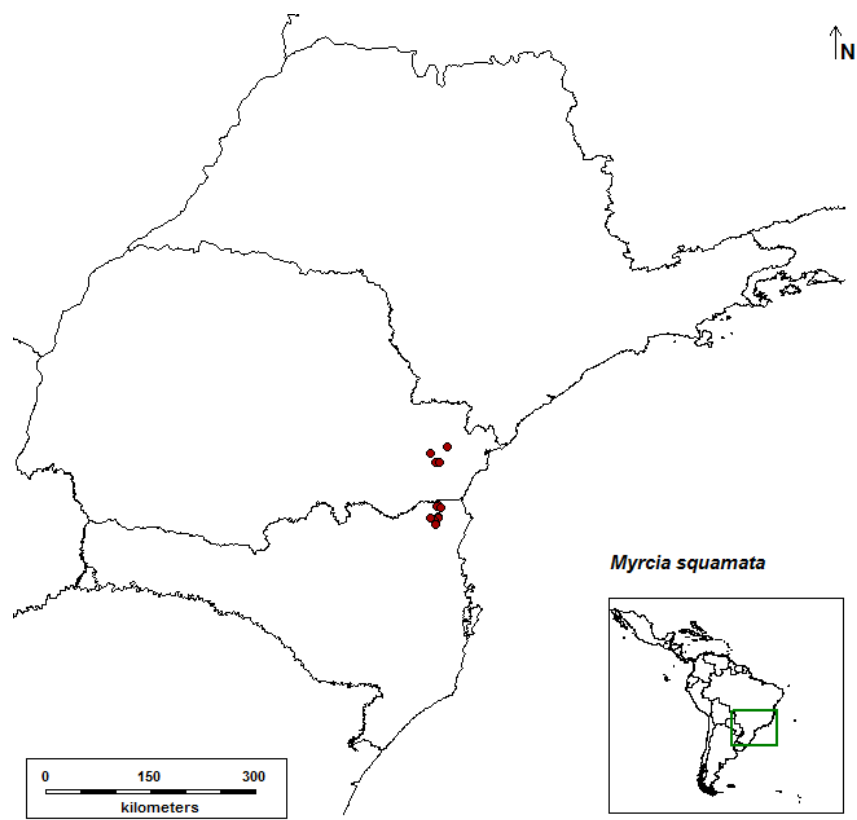

FiguRE 2. Distribution of Myrcia squamata (Mattos and D. Legrand) Mattos.

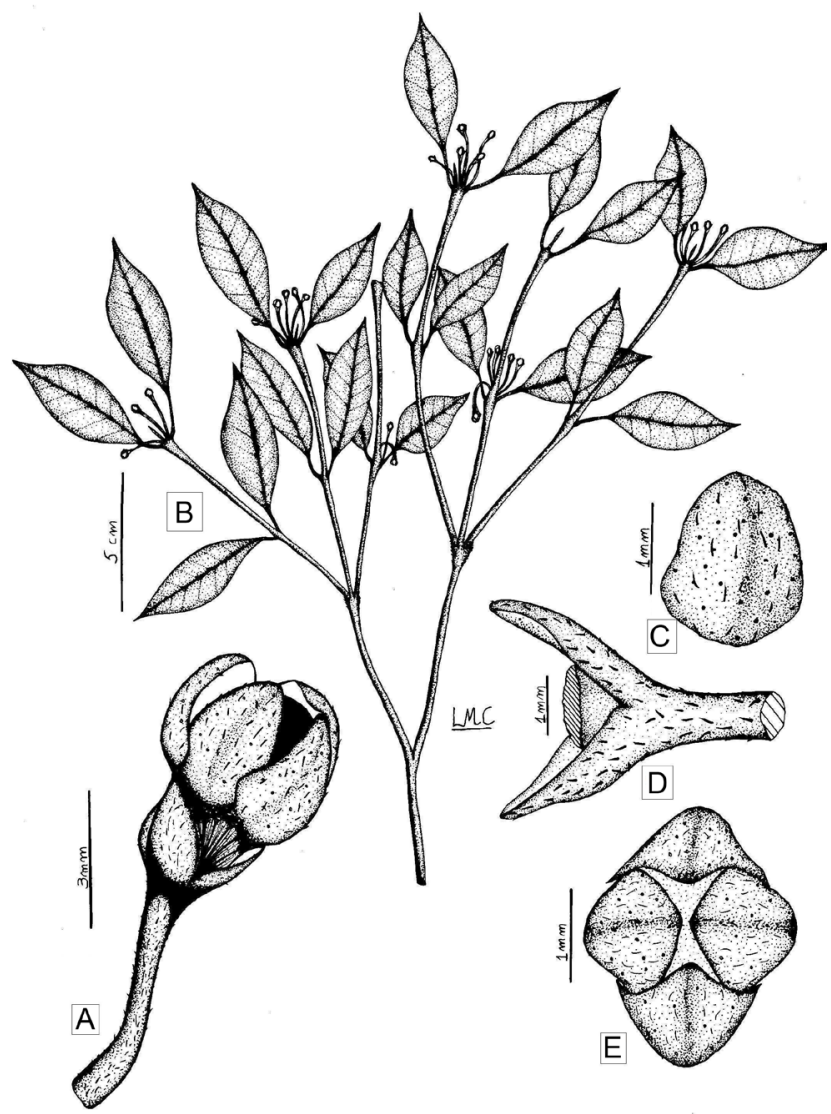

Figure 3. A) Young flower, B) branch, C) calyx lobe, D) bracteoles and pedicel, E) bud in upper vision.

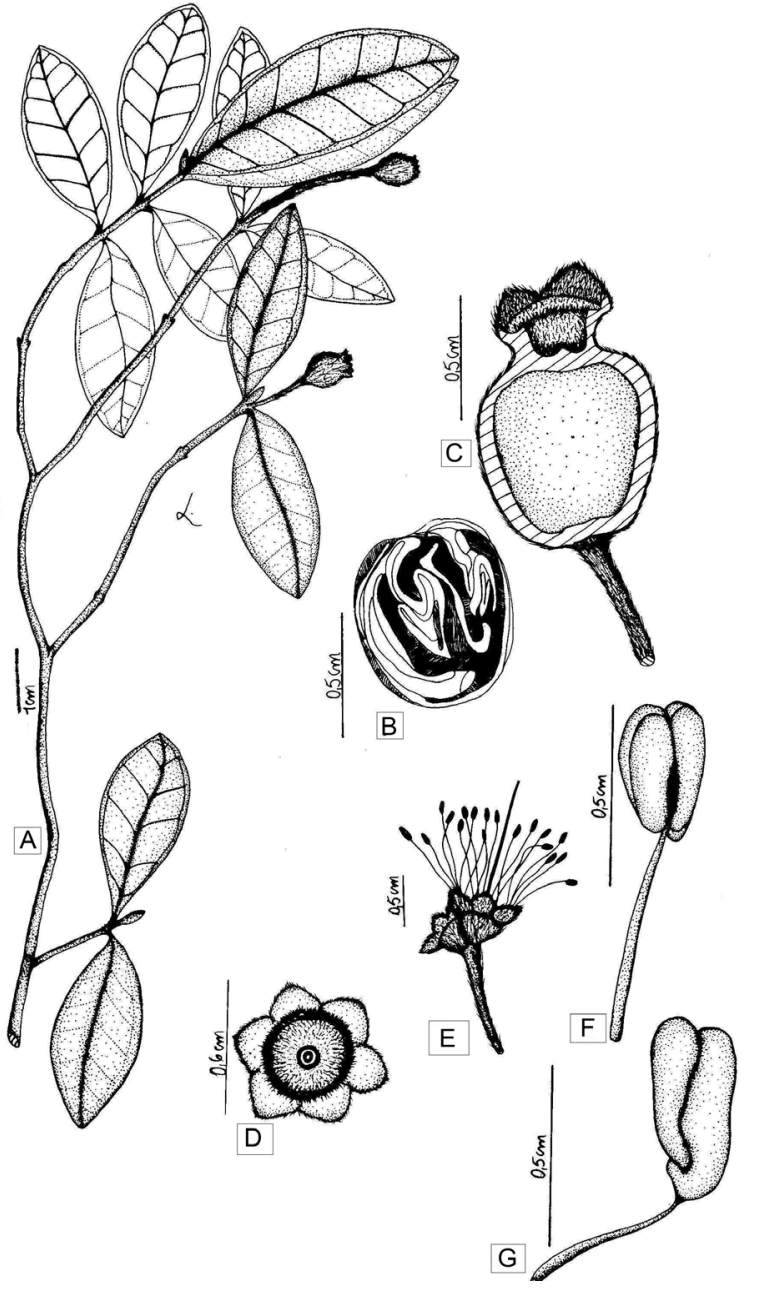

FigURE 4. A) Branch with young fruits, B) seed, C) fruit in cross section, D) ovary, E) flowers, F) stamen in front vision, G) stamen in side vision.

Myrcia squamata (Mattos and D. Legrand) Mattos, Loefgrenia 125: 4. 2008.

= Gomidesia squamata Mattos and D. Legrand, Loegfrenia 67:14. 1975.

Small tree $5 \mathrm{~m}$ high. Twigs covered by trichomes when young, scarce in mature branches, lenticels present. Leaves elliptic to obovate, 5,5-7x1,5-3cm, Peduncles 0,8-1,8cm, covered by trichomes. Inflorescences are short panicles. Corolla white, pentamerous, dialypetalous. Fruit fleshy, globose, $1,2 \times 1,0 \mathrm{~cm}$, reddish to purple when mature, covered with trichomes (Figure 4).

Geographic Distribution: Santa Catarina state: Joinville and Garuva; Paraná state: Campina Grande do Sul, Piraquara, Quatro Barras, São José dos Pinhais; Brasil: only over the Mountain ridge of the Sea, in Santa Catarina and Paraná state, ever between 700 and 1,200m asm (above sea level).

Material examined: BRAZIL. Santa Catarina: Joinville, Morro Jurapê, 11-VI-2006, fl., F.C.S. Vieira 1477(JOI). Joinville, Castelo dos Bugres, 24-VI-2004, fr., F.C.S. Vieira 381 (JOI). Ibidem, 28-VI-2004, F.C.S. Vieira 418 (JOI). Ibidem, 25-I-2005, fl., F.C.S. Vieira 800, (JOI). Ibidem, 21II-2005, fl., F.C.S. Vieira 844, (JOI). Ibidem, 26-III-2005, fl., F.C.S. Vieira 921, (JOI); Garuva, Monte Crista, 4-VII-2004, fr., F.C.S. Vieira 402 (JOI). Ibidem, fr., F.C.S. Vieira 1873, (JOI). Paraná: Campina Grande do Sul, G.G. Hatschbach 16862 (MBM); Piraquara, Mananciais da Serra, M. Reginato 697, 203 (MBM). 
ACKNowledgments: The authors thank Sidnei da Silva Dornelles and Cynthia Hering Rinnert for their help; Mariza Speck for financial support; Dr. Marcos Sobral, specialist in Myrtaceae, for identifications; curators and workers of following Herbaria: UPCB, HBR e MBM, specialy Dr. G. G. Hatschbach (MBM); and Biologist Luciano M. Ceolin, for illustrations.

\section{Literature Cited}

APG III. 2009. An update of the Angiosperm Phylogeny Group classification for the orders and families of flowering plants: APG III. Botanical Journal of the Linnean Society 161: 105-121.

CRIA 2008. SpeciesLink: Sistema de informação distribuído para coleções biológicas. Electronic Database accessible at http://splink.cria.org.br. Captured on 25 may 2008.

Judd, W.S., C.S. Campbell, E.A. Kellogg and .P.F Stevens. 1999. Plant systematics. A phylogenetic approach. Sunderland: Sinauer Asociates. $464 \mathrm{p}$.

Landrum, L.R. 1981. A monograph of the genus Myrceugenia (Myrtaceae). Flora Neotropica, Monograf 29: 1-137.

Landrum, L.R. 1984. Taxonomic implications of the discovery of caliptrate species of Myrceugenia (Myrtaceae). Britonia 36(2):161-166.

Landrum, L.R. and Kawasaki, M.L. 1997. The genera of Myrtaceae in Brazil: an illustrated synoptic treatment and identification keys. Brittonia 49: 508-536.

Legrand, C.D. and R.M. Klein 1967. Mirtáceas - Gomidesia; p. 1-44. In R. Reitz (ed.). Flora Ilustrada Catarinense. Itajaí: Herbário Barbosa Rodrigues.
Legrand, C.D., and R. M. Klein 1969. Mirtáceas - Myrcia; p. 217-330. In R. Reitz (ed.). Flora Ilustrada Catarinense. Itajaí: Herbário Barbosa Rodrigues.

Legrand, C.D., and R. M. Klein 1970. Mirtáceas - Myrceugenia; p. 331-453. In R. Reitz (ed.) . Flora Ilustrada Catarinense. Itajaí: Herbário Barbosa Rodrigues.

Legrand, C.D., and R. M. Klein 1977. Mirtáceas - Suplemento I; p. 1-34. In R. Reitz (ed.) . Flora Ilustrada Catarinense. Itajaí: Herbário Barbosa Rodrigues.

Lima, W.G., and R. R. Guedes-Bruni 2004. Myrceugenia (Myrtaceae) ocorrentes no Parque Nacional do Itatiaia, Rio de Janeiro. Rodriguésia 55 (85): 73-94.

Schultz, A.R.H. 1984. Introdução à botânica sistemática. 4. ed. Porto Alegre: UFRGS. 416 p.

Sobral, M. 2003. A família das Myrtaceae no Rio Grande do Sul. São Leopoldo: Unisinos. 218 p.

Veloso, H.P. 1992. Sistema fitogeográfico; p.9-38. In Instituto Brasileiro de Geografia e Estatística. Manual técnico da vegetação brasileira. Rio de Janeiro: IBGE.

RECEIVED: September 2009

REVISED: September 2009

ACCEPTED: September 2010

PUBLISHED ONLINE: October 2010

EDITORIAL RESPONSIBILITY: Frederico A. G. Guilherme 